\title{
Modified Risk Factors for Coronary Heart Disease (CHD) in Minahasa Ethnic Group From Manado City Indonesia
}

\author{
Ester Jeini Nelwan ${ }^{1,4}$, Edi Widjajanto ${ }^{2}$, Sri Andarini ${ }^{2}$, M. Sasmito Djati ${ }^{3}$ \\ ${ }^{1}$ Doctoral Program of Environmental Science, University of Brawijaya, Malang, Indonesia \\ ${ }^{2}$ Faculty of Medicine, University of Brawijaya, Malang, Indonesia \\ ${ }^{3}$ Faculty of Mathematics and Natural Sciences, University of Brawijaya, Malang, Indonesia \\ ${ }^{4}$ Faculty of Public Health, Sam Ratulangi University, Manado, Indonesia
}

\begin{abstract}
Coronary heart disease (CHD) is a non-transmitted disease which is particular concern at the global, national, and local level. CHD has become a concern because it has caused a lot of deaths. Risk factors linked with CHD consist of permanent risk factors and variable risk factors. The purpose of the research is to analyze the correlation between variable risk factors and CHD in the Minahasa ethnic society in Manado City. This research was an observational casecontrol study conducted by Prof. dr. R. D. Kandou Hospital, Manado, from August to October 2016. In total, there were 220 patients included. The sampling used a simple random sampling method and the data obtained were analyzed by chi-squared test. According to the results, hypertension, smoking, and behavioral type were connected to cases of CHD. The correlation degree showed that the respondents suffering hypertension were 5.70 times more likely to suffer CHD, the smoking respondents were 2.25 times more likely to experience, and behavior type A respondents were 2.96 times more likely to suffer CHD. Hypertension, smoking, and behavioral type are linked with CHD, so there should be some promotion and preventive actions from the health governmental institution to society, especially aimed at adults, about the quality of life enhancement by healthy behavior and avoiding CHD risk factors.
\end{abstract}

Keywords: behavioral type, Case-control study, hypertension, smoking behavior.

\section{INTRODUCTION}

Millennium Development Goals are connected strongly with health. One of them is nontransmitted diseases, especially cardiovascular disease (CVD). According to the World Heart Federation [1], CVD is connected with 8millennium development goals. CVD is connected strongly with poverty, as this is one of the CVD risk factors; also, CVD can cause poverty. Several types of research show that CVD results in a number of deaths; $80 \%$ of these deaths are reported in poor countries. CVD is also connecting to basic education. Education is one of the risk factors of CVD, and CVD is the first cause death of women. Decreasing the number of child deaths and increasing maternal health are also connected to CVD. Smoking behavior and unhealthy lifestyle on the mother's side can cause CVD in mothers and children. In addition, CVD is one of the keys to fighting HIV/AIDS, malaria, and other diseases, as CVD is the main cause of death of HIV/AIDS patients.

\footnotetext{
${ }^{*}$ Correspondence author:

Ester Jeini Nelwan

Email : jeini83@gmail.com

Address : Graduate School, University of Brawijaya, Mayjen Haryono 169, Malang 65145
}

Unhealthy lifestyle choices, such as smoking, lack of activity, stress, and so on, can cause several types of degenerative diseases. In the last few years, non-transmitted diseases have dominated as the main cause of death globally [2]. Non-transmitted diseases have increased significantly in developing countries, which have demographic transition and lifestyle changes in their society [3]. The number of deaths caused by CVD, such as coronary heart disease (CHD), stroke and other rheumatic heart diseases, is increasing globally. The World Health Organization predicts that around 20 million deaths will have been caused by CVD in 2015. This accounts for $30 \%$ of all deaths in the world [4]. It is predicted that by the year 2030, non-transmitted diseases will account for more than threequarters of all deaths worldwide. The dominant cause of death in low-income countries is CVD. The case numbers are higher than those of transmitted diseases (including HIV/AIDS, tuberculosis, and malaria), antenatal and prenatal conditions, and nutrient disturbance [5].

Therefore, CVD now is the leading contributor to death globally and will continue to dominate in the future. CVD deaths were increased by 3.1 million to 17.5 million in 2005 from 14.4 million in 1990 . From these numbers, around 7.6 million 
were caused by CHD and 5.7 million by stroke. More than $80 \%$ of deaths occurred in low and middle-income countries [6].

CHD was seldom found in Indonesia before 1950. However, in the early 1970s, CHD was the most commonly found heart disease in many hospitals in Indonesia. According to the Survey Kesehatan Rumah Tangga Departemen Kesehatan RI (Household Health Survey of Health Department of Indonesia) in 1986, it was reported that morbidity of heart disease and blood vessel disease increased from the tenth place in 1981 to third in 1986. This increase was caused by the morbidity of CHD [7].

The etiology or risk factors of CHD are multifactorial. This is a result of interactions between genetics, lifestyle, and environmental factors. A risk factor can be classified into permanent, such as age, gender or family history, or modified, like smoking, hypertension, diabetes mellitus, obesity, and so on. Heart and blood vessel disease has been reported to be the main cause of death in Indonesia since 1995, and is now beginning to threaten and affect the young. In the beginning, CHD was only found in those aged 45 and above, but according to the data in several hospitals, CHD cases are now found in youths aged 27-32 years old. This is because risk factors caused by lifestyle are changing with time and civilization [8].

The results of the National Social Economy Survey in 2004 showed that economic growth, social culture, and technology development have not only positively influenced but also caused changes that negatively affect health, especially with regard to the heart [9]. This can be seen by increasing tobacco consumption, decreasing physical/sports activity, and so on. Based on the results of that survey, it was found that $14.3 \%$ of children have been smoking since under 15 years of age. Also, the percentage of people aged 15 years old and over who do physical/sports activity is just $18 \%$.

CHD has also become an important health concern in Sulawesi Utara (Northern Celebes). According to Indonesia Basic Health Research (Riskesdas) in 2013, CHD prevalence is $0.7 \%$ [10]. This is above the national level of $0.5 \%$, and is the second highest in Indonesia. This is because risk factors of CHD such as obesity, smoking behavior, diabetes mellitus, and hypertension have quite a high prevalence in these areas.

Based on Riskesdas data from 2010, the prevalence of obesity in North Celebes is the highest in Indonesia, at $21.9 \%$ (national prevalence is
11.7\%). The 2013 Riskesdas results show that the prevalence of obesity in Northern Celebes had increased to $24.0 \%$ (national prevalence is $15.4 \%)$, which is still the highest in Indonesia [11].

According to Riskesdas in 2007, 2010, and $2013[10,11,12]$, the number of smokers in Indonesia increased from $34.2 \%$ [10] to $34.7 \%$ [11] and reached $36.3 \%$ in 2013 [12]. Based on 2010 Riskesdas data, the smoker prevalence in Northern Celebes is above the national level of $36.2 \%$. Furthermore, according to 2013 Riskesdas data, the prevalence of hypertension in Northern Celebes is around $27.1 \%$ (national prevalence is $25.8 \%$ ). The prevalence of diabetes mellitus is around $3.6 \%$ (national prevalence is $2.1 \%$ ). This shows that CHD is predicted to increase in Indonesia, especially in Northern Celebes. The population of Northern Celebes consists of several ethnicities, dominated by the Minahasa population. The purpose of this research is to analyze the correlation degree of modified risk factors with CHD cases in Minahasa individuals from Manado City, Indonesia.

\section{MATERIALS AND METHODS Study Site}

This research was a non-comparable casecontrol study. The research location was Manado City, which is the capital of Northern Celebes. It lies geographically in $124^{\circ} 40^{\prime}-124^{\circ} 50^{\prime} \mathrm{E}$ and $1^{\circ} 30^{\prime}-1^{\circ} 40^{\prime} \mathrm{N}$. Manado City bounds the District of Minahasa Utara (Northern Minahasa) in the north, the District of Minahasa in the south, the District of Minahasa Utara and Minahasa in the east, and the Gulf of Manado in the west. This research was conducted from August-October 2016.

\section{Population and Sample of Research}

The population of this research was all CHD patients who attended the Cardiac Brain and Vascular Center (CBVC) in RSUP Prof. Dr. R.D. Kandou, Manado. This hospital was selected because it is the CHD reference center in the North Sulawesi Province. The number of samples was calculated using the Budiarto formula [13], so that 110 patients were selected for the cases and 110 patients for controls, making a total of 220 patients. Simple random sampling was the sampling method selected.

In this research, samples consisted of cases and controls. The cases were outpatients who received treatment in CBVC of RSUP Prof. Dr. R.D. Kandou Manado, following a diagnosis of $\mathrm{CHD}$ by 
a heart specialist based on clinical manifestation and electrocardiography (ECG) examination. The control group was outpatients who were treated in the general internal clinic in RSUP Prof. Dr. R.D. Kandou Manado but had not been diagnosed with CHD based on clinical symptoms and electrocardiography (ECG) examination. Inclusion criteria were the respondent providing a signed informed consent, receiving treatment for a maximum of one-year with the expectation that the respondent still could remember the habits and events that they've experienced, and attended when the research was conducted. Exclusion criteria were a disorder in communication and any mental disorder.

\section{Variable of Research}

The variables investigated in the research were hypertension, smoking, and behavior type as independent variables, with $\mathrm{CHD}$ as the dependent variable. This study was performed in the dichotomous (two groups) form. CHD was categorized as "Yes" if it fulfilled the operational definition of a CHD patient and "No" if the operational definition of a CHD patient was not fulfilled. Hypertension used the criteria based on JNC 7, which was "hypertension" if systolic blood pressure $\geq 140 \mathrm{mmHg}$ or diastolic $\geq 90 \mathrm{mmHg}$ and "not hypertension" if systolic blood pressure $<140 \mathrm{mmHg}$ or diastolic $<90 \mathrm{mmHg}$. Smoking was assessed using the criteria "smoker" if the patient had ever smoked and "non-smoker" if the patient had never smoked. The behavior type consists of types A and B. A-type individuals could not get a postponement, could not be easily told to rest, and worked to their maximum capacity, even if this work was not important, while B-type people had the opposite characteristics. Behavior type criteria according to Nababan [14] consists of A-Type if the total value obtained by the respondent $\geq 34$ and B-Type if the total value obtained by the respondent $<34$.

\section{Data Analysis}

The data obtained were analyzed in a univariate manner, bivariate using the chi-squared test and multivariate using the logistic regression test.

\section{RESULTS AND DICUSSION}

Cross-tabulation was performed between respondent status and independent variables (hypertension, smoking habit, and behavior type). The results are shown in Table 1.
Table 1. Cross tabulation among variables.

\begin{tabular}{|c|c|c|c|c|}
\hline \multirow{2}{*}{$\begin{array}{l}\text { Respondent Charac- } \\
\text { teristic }\end{array}$} & \multicolumn{4}{|c|}{ Respondent Status } \\
\hline & Case & $\%$ & Control & $\%$ \\
\hline \multicolumn{5}{|l|}{ Blood Pressure } \\
\hline a. Hypertension & 92 & 83.6 & 52 & 47.3 \\
\hline b.No & 18 & 16.4 & 58 & 52.7 \\
\hline Total & 110 & 100.0 & 110 & 100.0 \\
\hline \multicolumn{5}{|l|}{ Smoking Habit } \\
\hline a. Yes & 64 & 58.2 & 42 & 38.2 \\
\hline b.No & 46 & 41.8 & 68 & 61.8 \\
\hline Total & 110 & 100.0 & 110 & 100.0 \\
\hline \multicolumn{5}{|l|}{ Behavior Type } \\
\hline а. Type A & 65 & 59.1 & 37 & 33.6 \\
\hline b.Type B & 45 & 40.9 & 73 & 66.4 \\
\hline Total & 110 & 100.0 & 110 & 100.0 \\
\hline
\end{tabular}

Table 1 shows that the hypertension respondents are mostly in the case group (83.4\%), as are smoking respondents (58.2\%), and the A-type behavior-type respondents (59.1\%). An association between independent variables and $\mathrm{CHD}$ cases was then performed (Table 2).

Table 2. Correlation among Research Variable

\begin{tabular}{|c|c|c|c|}
\hline $\begin{array}{l}\text { Respondent } \\
\text { Characteristic }\end{array}$ & $\begin{array}{c}\text { OR } \\
\text { (Crude) }\end{array}$ & $95 \% \mathrm{Cl}$ & $p$ value \\
\hline \multicolumn{4}{|l|}{ Hypertension } \\
\hline a. No & 1.000 & reference & \\
\hline b. Yes & 5.701 & $3.040-10.690$ & 0.000 \\
\hline \multicolumn{4}{|l|}{ Smoking Habit } \\
\hline a. No & 1.000 & reference & \\
\hline b. Yes & 2.253 & $1.313-3.865$ & 0.003 \\
\hline \multicolumn{4}{|l|}{ Behavior Type } \\
\hline a. B & 1.000 & reference & \\
\hline b. A & 2.959 & $1.708-5.127$ & 0.000 \\
\hline
\end{tabular}

Description: OR=Odds Ratio, $\mathrm{Cl}=$ Confidence Interval

Table 2 shows the correlation between hypertension and CHD cases, with the hypertension respondents are probably suffering CHD 5.70 times more often than those who do not suffer hypertension. The correlation between smoking habit and CHD shows that smokers probably suffer CHD 2.25 times more often than nonsmokers. The correlation between behavior type and CHD case shows that there is a significant correlation, with type-A behavior respondents probably suffering CHD 2.96 times more likely than the type-B behavior individuals.

The correlation between hypertension and CHD case in this research is parallel with the research conducted by Nababan [14], which showed that there is a significant correlation between hypertension and CHD cases $(p<0.05$ and $O R$ 2.25). OR value also shows that the hypertension respondents have a risk of developing CHD 
2.25 times more than those who do not suffer from hypertension.

Furthermore, previous study performed research into CHD risk factors in type 2 diabetes mellitus patients in RSUP Dr. Kariadi Semarang [15] and showed that there is a correlation between hypertension and CHD, with a p-value of 0.007 and $\mathrm{OR}=2.77(95 \% \mathrm{Cl}=1.436-9.725)$. This shows that the hypertension respondents have a 2.77 times higher risk of CHD than those who do not suffer hypertension.

Research conducted into prevalence and risk factors for CHD in a downtown area of Bangladesh found that hypertension respondents have a 2.14 times higher risk (systolic blood pressure) and or a 1.93 times higher risk of CHD (diastolic blood pressure) than those with a normal blood pressure [16].

The research conducted by Setiani [17] in the reproductive age group ( $<55$ years old) in RSU Dr. Soetomo Surabaya using a case-control design found that hypertension correlates significantly with CHD (OR value $=27.44$ ) and women aged $>45$ years old correlate with $\mathrm{CHD}$ (OR value = 12.25). Hereafter, this is explained by smoking and dietary habits not having a significant correlation with $\mathrm{CHD}$.

The Framingham research results also showed a correlation between CHD and diastolic blood pressure. The myocardial infarction cases were twice as common in the group with a diastolic blood pressure of $90-104 \mathrm{mmHg}$ compared to the $85 \mathrm{mmHg}$ diastolic blood pressure group, while the risk at a diastolic blood pressure of 105 $\mathrm{mmHg}$ was four times higher. The Stewart experiments in 1979 and 1982 also confirmed the correlation between increased diastolic blood pressure and the risk of suffering a myocardial infarction. If systolic and diastolic hypertension occurs together, this confers the greatest risk compared to normal blood pressure or systolic hypertension patients. Lichenster also reported that CHD death is more closely correlated to systolic-diastolic blood pressure than just diastolic blood pressure [18].

Several studies have also shown the correlation between hypertension and CHD, like the research conducted in Manipal Education Hospital in Pokhara City and showed that there is a correlation between hypertension and heart attack cases, in this case CHD [19].

Research conducted by the Secretariat of the Pacific Community (SPC) in 2002 in New Caledonia showed that individuals with hypertension have a higher risk of CHD, stroke, heart failure, and kidney disease [20]. The Louisiana Department of Health published a survey conducted about risk factors for heart disease and stroke which shows that hypertension is one of the main risk factors for $\mathrm{CHD}$.

Other research about heart disease and stroke and found that blood pressure more than $120 \mathrm{mmHg}$ (systolic) and $80 \mathrm{mmHg}$ (diastolic) consistently increases the risk of CHD [22]. According to The Women's Health Resource, hypertension either alone or in combination with obesity, smoking, hypercholesterolemia, and diabetes can increase the risk of CHD [23].

$A$ research that investigated the link between hypertension and CHD showed that there are correlations between $\mathrm{CHD}$ respondents and hypertension [24]. Other study showed several results indicating that $90 \%$ of essential hypertension cases occur in adults, with the other $10 \%$ of cases being caused by some chronic states; furthermore, it was found that almost all CHD patients are hypertension patients [25].

Research into hypertension, $\mathrm{CHD}$, and death in Afro-American males and females in the USA, showed that $\mathrm{CHD}$ is the main cause of death in the United States and many patients, are AfroAmerican [26]. Next, it was found that hypertension correlates with CHD cases in Afro-American individuals in the USA. An article written by the World Heart Federation about cardiovascular disease risk factors showed that CHD is caused by several factors, such as hypertension, tobacco use (smoking), alcohol consumption, high cholesterol, lack of physical activity, and unhealthy diets [1].

CHD and hypertension which included some facts suggesting that hypertension is one of the main risk factors causing CHD [27], which can cause death via heart failure (45\%), myocardial infarction (35\%), cerebrovascular disease (15\%), and kidney failure (5\%). The Framingham research also reported a correlation between CHD and diastolic blood pressure. Myocardial infarction cases are two times higher in the group with a diastolic blood pressure of 90-104 mmHg compared to the $85 \mathrm{mmHg}$ diastolic blood pressure group, and $105 \mathrm{mmHg}$ diastolic blood pressure patients have a four times higher risk of developing CHD. Furthermore, it is known that CHD deaths are more closely correlated to systolic blood pressure than diastolic blood pressure.

Medicinal treatment of hypertension can prevent myocardial infarction and left ventricle failure, but attention must also be paid to side effects of the medicines in the long-term. There- 
fore, the prevention of hypertension is a better effort for decreasing CHD risk. Dietary sodium (Na) and potassium (K) consumption are factors related to life patterns. Physical fitness also correlates with systolic blood pressure [18], in which people with optimum physical fitness tended to have low blood pressure. The research in the United States reported in the last decade has shown a decrease in CHD deaths by $25 \%$. This condition may be caused by the result of early detection and treatment of hypertension, use of beta-blockers and coronary surgery and changing smoking habits.

For adults aged 40-69 years old, each 20 $\mathrm{mmHg}$ systolic heart pressure or $10 \mathrm{mmHg}$ diastolic blood pressure increases doubles the risk of death by CHD [28]. Blood pressure is assumed to be high if it stays at or above $140 / 90 \mathrm{mmHg}$ from time to time. If someone suffers from diabetes or chronic kidney disease, then they are considered to be hypertensive if their blood pressure is $130 / 80 \mathrm{mmHg}$ or higher [29]. The Interheart research showed that $22 \%$ of heart attack cases in Western Europe are caused by hypertension. Hypertension increases the risk of heart attack by almost two times [30].

The correlation between smoking habit and $\mathrm{CHD}$ in this research is similar to research by $\mathrm{Na}-$ baban [14] which stated that a smokers have a 2.51 times higher chance of developing CHD than non-smokers. Supriyono [31] showed that those who smoke have a 2.3 times higher risk of $\mathrm{CHD}$ below 45 years old than those who do not smoke.

Deaths caused by CHD are $60 \%$ higher in smokers [32]. The routine impact of passive smoking increases CHD risk by $25 \%[33,34]$. In 2000, about 1 in 8 deaths in the United Kingdom are caused by cardiovascular disease due to smoking. Based on WHO research, it is predicted that more than $20 \%$ of $\mathrm{CHD}$ cases are caused by smoking [35].

Smoking can damage and tighten blood vessels, cause unhealthy cholesterol levels, and increase blood pressure. Smoking also can limit the amount of oxygen reaching body tissues [29]. Smoking is one of main risk factors for $\mathrm{CHD}$. Some reports have shown that the CHD risk is $2-4$ times higher in male and female heavy smokers ( $>20$ cigarettes per day) than in those who do not smoke. Smoking risk works synergistically with other factors, like hypertension, fat level, or high blood sugar level with regard to developing CHD. It is important to know that death risk caused by CHD decreases by $50 \%$ in the first year after smoking cessation. Smoking gives a bigger risk of CHD than obesity $[36,37]$. Female smokers are at a higher risk of developing CHD because female smokers can undergo early menopause and have reduced levels of estrogen. Smoking accelerates $\mathrm{CHD}$ and stroke in women. Smoking is known to cause health problems. This health disorder can be caused by nicotine from primary and secondary smoke being consumed by the individual; therefore, the sufferers are not only the smoker himself/herself (active smoker), but also people in their environment, so-called passive smokers [38].

The role of smoking in CHD is due to the smoke fumes containing nicotine, which cause the release of substances like adrenalin. This stimulates the heart rate and blood pressure. Smoke fume also contains carbon monoxide (CO) which has the ability to absorb oxygen more strongly than hemoglobin, thus decreasing the hemoglobin capacity to bring oxygen to the tissues, including the heart. This should be given attention, especially for CHD, because arterial blood vessels with plaques have less blood flow than normal. Smoking can hide angina, which is an ache in the chest that can be the sign of a heart attack. Without that sign, the patient will not realize that there are dangerous diseases attacking people, and will therefore not take appropriate action. Smokers probably have a risk of experiencing a stroke that is two or three times higher than people who do not smoke. Smoking continuously in the long-term causes an increased probability of suffering artery stoppage in the neck, regardless of how many cigarettes were consumed daily. Smokers have low HDL blood cholesterol levels, which mean that the protective element of CHD is decreasing. Also, smokers more easily develop leg spasms during sport or physical activities, because of occlusions in the arterial vessels in the legs [39].

Nicotine activates platelets causing platelet adhesion to the blood vessel walls. Carbon monoxide (CO) and other substances in the smoke have been proven to damage endothelial walls (blood vessel walls) and ease blood coagulation. Platelet coagulation causes peripheral blood vessel damage. Smoking one cigar a day will increase systolic blood pressure by $10-25 \mathrm{mmHg}$ and increase the heart rate by 5-20 beats a minute [40]. This research also reported results that behavior type is related to $\mathrm{CHD}$, which is in parallel to $\mathrm{Pa}$ tel's study [41], reporting that $A$ behavior type is reflected by certain physiological reactions, like increased blood pressure, increased adrenalin 
production, and increased platelet adhesiveness, which enhances the probability of blood coagulation. A human with type-A behavior cannot accept the delay and does not find it easy to rest, usually working at their maximum capacity, and not admitting to tiredness and fatigue; therefore, they will keep working and almost lose power. Researchers have shown that people with type-A behavior have a two times higher risk of dying from a heart attack than those who have type-B behavior [41].

\section{CONCLUSION}

Conclusion of the study's findings are written According to this research, it can be concluded that hypertension, smoking, and behavior type are related to CHD. Hypertension respondents have a probability of suffering from CHD that is 5.70 times higher than those who do not suffer from hypertension. Smokers have a probability of suffering CHD that is 2.25 times higher than in those who do not smoke. Also, type-A behavior type respondents have a probability of developing CHD that is 2.96 times higher than those who have type-B behavior. Therefore, promoting variable risk factors is recommended, as individuals must have healthy lifestyles to decrease the risk of $\mathrm{CHD}$.

\section{REFERENCES}

[1] World Heart Federation. 2011. Cardiovascular disease risk factors. Available at: http://www.whd.chd/riskfactors.

[2] Anies. 2006. Waspada ancaman penyakit tidak menular. PT. Gramedia. Jakarta.

[3] World Health Organization. 2008. WHO disease and injury country estimates. World Health Organization. Geneva.

[4] World Health Organization. 2005. Preventing chronic diseases: A vital investment. Available at: http://www.who. int/chp/chronic_disease_report/full_report. pdf.

[5] Beaglehole, R., R. Bonita. 2008. Global public health: a scorecard. Lancet. 372 (9654). 1988-1996.

[6] World Health Organization. 2009. WHO disease and injury country estimates. World Health Organization. Geneva.

[7] Sargowo, D. 2002. Tipe perilaku tipe A (PPTA) pada penderita PJK. Medical Faculty. University of Brawijaya. Malang.

[8] Wilson, P.W., R.B. D'Agostino, D. Levy, A.M. Belanger, H. Silbershatz, W.B. Kannel. 1998. Prediction of coronary heart disease using risk factor categories. Circulation. 97(28). 1837-1847.

[9] National Statistic Center. National Social Economy Survey 2004. National Statistic Center. Jakarta.

[10] Research and Development of Health. 2007. Basic Health Research 2007. Ministry of Health Indonesia. Jakarta.

[11] Research and Development of Health. Basic Health Research Indonesia 2010. Ministry of Health Indonesia. Jakarta.

[12] Research and Development of Health. 2013. Basic Health Research Indonesia. Ministry of Health Indonesia. Jakarta

[13] Budiarto, E. 2003. Penelitian kasus kontrol, metodologi penelitian kedokteran: sebuah pengantar. EGC. Jakarta

[14] Nababan, D. 2008. Hubungan faktor risiko dan karakteristik penderita dengan kejadian penyakit jantung koroner di RSU Dr. Pringadi Medan tahun 2008. Master Thesis. Graduate School, University of South Sumatera. Medan.

[15] Yanti, S., Hadisaputro, T. Suhartono. 2009. Risk factors Coronary Heart Disease in Type 2 Diabetes Mellitus patient (case study at RSUP dr. Kariadi Semarang). Master Thesis. Graduate School, Diponegoro University. Semarang.

[16] Sayeed, M.A., H. Mahtab, S. Sayeed, T. Begum, P.A. Khanam, A. Banu. 2010. Prevalence and risk factors of Coronary Heart Disease in rural population of Bangladesh. J. Ibrahim Med. Coll. 4(2). 3743.

[17] Setiani, R. 2009. Faktor risiko yang berhubungan dengan kejadian Penyakit Jantung Koroner (PJK) pada kelompok umur produktif ( $<5$ tahun). Master Thesis. Faculty of Public Health. Airlangga University. Surabaya.

[18] Kabo, P. 2008. Mengungkap pengobatan Penyakit Jantung Koroner, kesaksian seorang ahli jantung dan ahli obat. Gramedia Pustaka Utama. Jakarta.

[19] Shankar, P.R., P. Partha, N. Shenoy, T.S. Chandrasekhar, A.K. Dubey. 2007. Knowledge about heart attack and hypertension among individuals attending a cardiac camp in Pokhara City. Kathmandu Univ. Med. J. 5(2). 237-278.

[20] Secretariat of the Pacific Community. 2002. Heart disease and hypertension : factsheet number 8. Life Style Section. New Caledonia. 
[21] The Louisiana Departement of Health. 2007. The Louisiana State plan for the prevention and treatment of heart disease and stroke 2007-2012. The Centers for Disease Control and Prevention, Division for Heart Disease and Stroke Prevention, State Heart Disease and Stroke Prevention Programs. Louisiana.

[22] Fortman, S.P., A.N. Varady. 2000. Effects of community-wide health education program on cardivascular disease morbidity and mortality : The Stanford Five City Project. Am. J. Epidemiol. 1(152). 316-323.

[23] The Women's Health Resource. 2010. Heart Disease-Myocarial Infarction (heart attack). Available at: http://www.imagine.com/ heart_disease.

[24] Richardson, P.J., L.S. Hill. 1979. Relationship between hypertension and angina pectoris. Brit. Journal Clin. Pharmaco. 7(2). 249-253.

[25] Riaz, K., A. Ahmed. 2010. Hypertension and heart disease. Available at: http://www. hypertension_heartdisease.com.

[26] Schwantdt, H.M., J. Coresh, M.J. Hindia. 2010. Marital status, hypertension, Coronary Heart Disease, diabetes and death among African American women and men : incidence and prevalence in the Atherosclerosis Risk in Communities (ARIC). J. Fam. Issue. 3(9). 1211-1229.

[27] Djohan, B.A. 2004. Penyakit Jantung Koroner dan hipertensi. Jurnal USU. 3(5). 120.

[28] Lewington, S., R. Clarke, N. Qizilbash. 2002. Age-specific relevance of usual blood pressure to vascular mortality: a metaanalysis of individual data for one million adults in 61 prospective studies. Lancet. 360(9349). 1903-1913.

[29] National Heart, Lung, and Blood Institute. 2014. Hypertension. National Heart, Lung, and Blood Institute. US.

[30] Yusuf, S., S. Hawken, S. Ounpuu. 2002. Effect of potentially modifiable risk factors associated with myocardial infarction in 52 countries (the INTERHEART study): casecontrol study. Lancet. 364(9438). 937-952.

[31] Supriyono, M. 2008. Faktor-faktor risiko kejadian jantung koroner pada usia $\leq 45$ tahun (studi kasus di RSUP dr. Kariadi Semarang dan RS Tegalrejo Semarang). Master Thesis. Diponegoro University. Semarang.

[32] Doll, R., R. Peto, J. Boreham. 2004. Mortality in relation to smoking: 50 years' observations on male British doctors. BMJ. 328(7455).

[33] Law, M.R., J.K. Morris, N.J. Wald. 1997. Environmental tobacco smoke exposure and ischaemic heart disease: an evaluation of the evidence. BMJ. 315(7114). 973-980.

[34] He, J., S. Vupputuri, K. Allen. 1999. Passive smoking and the risk of coronary heart disease--a meta-analysis of epidemiologic studies. N. Engl. J. Med. 340(12). 920-926.

[35] Guilbert, J.J. 2003. The world health report 2002 - reducing risks, promoting healthy life. Educ Health (Abingdon). 16(2). 230.

[36] Kromhout, D., B. Bloemberg, E. Feskens, A. Menotti, A. Nissinen. 2000. Saturated fat, vitamin $\mathrm{C}$ and smoking predict long-term population all-cause mortality rates in the seventh Countries Study. Int. J. Epidemiol. 4(3). 321-330

[37] Adiwiyoto, A. 2003. Kolesterol. Kesain Blanc. East Bekasi.

[38] Dube, M.F., C.R. Green 1992. Methods of collection of smoke analytical purposes. Recent Advances in Tobacco Science. Nature. 8. 42-102.

[39] Amstrong, S. 1995. Pengaruh rokok terhadap, $3^{\text {rd }}$ Ed. Penerbit Arcan. Jakarta.

[40] Mangku, S., 1997. Usaha mencegah bahaya merokok. Gramedia. Jakarta.

[41] Patel, C. 1998. Petunjuk praktis mencegah dan mengobati penyakit jantung koroner. Gramedia. Jakarta. 